\title{
EXTENDED TABLE OF CONTENTS
}

List of figures $\quad x$

List of tables $\quad$ xxi

Editors and Contributors $\quad$ xxii

Foreword Sir Robin Jacob $\quad$ xxviii

Introduction Irene Calboli and Jacques de Werra $\quad x x x$

Table of cases $\quad$ xxxiv

Table of legislation xlvii

\section{PART I TRADEMARK TRANSACTIONS IN THE GLOBAL MARKETPLACE}

\section{Section A International Framework}

1. TRIPS, TRADEMARKS, AND TRADEMARK TRANSACTIONS:

\section{A FORCED RECONCILIATION?}

\section{Daniel J. Gervais}

A. INTRODUCTION $\quad 1.01$

B. THE ORIGIN OF THE TRADEMARK PROVISIONS IN THE TRIPS AGREEMENT

1. The battle between common and civil law 1.03

2. Trademarks in major legal systems and the TRIPS Agreement 1.08

3. The TRIPS Agreement and the Paris Convention 1.14

C. THE TRADEMARK PROVISIONS IN THE TRIPS AGREEMENT $\quad 1.17$

1. Article 15 of the TRIPS Agreement 1.18

2. The function(s) of trademarks $\quad 1.20$

3. Recordal of transfers and licenses under Article 19.2 of the TRIPS Agreement 1.29

4. Article 20 of the TRIPS Agreement 1.36

D. THE TRADEMARK TRANSACTIONS PROVISION: ARTICLE 21 OF THE TRIPS AGREEMENT 1.43

1. Drafting history 1.44

2. Compulsory licenses of trademarks $\quad 1.49$

3. Conditions on transfers and licenses and the enforcement of marks 1.54

4. A role for competition law?

E. CONCLUSION $\quad 1.70$

2. TRADEMARK TRANSACTIONS AND THE NORMATIVE FRAMEWORK OF THE WORLD INTELLECTUAL PROPERTY ORGANIZATION Marcus Höpperger
A. INTRODUCTION
B. THE NORMATIVE FRAMEWORK OF WIPO
1. The Paris Convention
2. The Singapore Treaty
3. The Joint Recommendation
4. The Madrid Protocol
C. CHANGE IN OWNERSHIP
1. The Paris Convention
2. The TLT and Singapore Treaty
3. The Madrid System 
D. LICENSES $\quad 2.30$

1. The Singapore Treaty and Joint Recommendation 2.30

2. The Madrid System $\quad 2.44$

E. RESTRICTIONS OF THE RIGHT OF DISPOSAL $\quad 2.47$

F. CONCLUSION

\section{Section B Strategic Considerations}

3. LICENSING COMMERCIAL VALUE: FROM COPYRIGHT TO TRADEMARKS AND BACK

Jane C. Ginsburg

A. INTRODUCTION

B. WHEN THE TRADEMARK OWNER IS NO LONGER A COPYRIGHT OWNER: TRADEMARK LICENSING IN THE SHADOW OF DASTAR

1. Distinguishing trademark goodwill from works of authorship 3.07

2. Trademark and copyright: in fact inseparable? $\quad 3.11$

3. Keeping characters out of the copyright public domain: the impact on trademarks 3.16

C. EXPLOITING CHARACTERS WHEN THE TRADEMARK CLAIMANT WAS NOT ORIGINALLY OR IS NO LONGER THE COPYRIGHT OWNER

1. Adopting copyright-expired characters

2. Reversion of copyright in a trademarked character

D. WHEN THE TRADEMARK OWNER BECOMES A COPYRIGHT OWNER: TRADEMARKS AS COPYRIGHTED WORKS

E. CONCLUSION

4. THE COMPLEXITIES OF DOMAIN NAMES TRANSACTIONS: CONTRACTS FOR A MARKET WHERE VALUE INCREASES WITH TIME

\section{Cédric Manara}

A. INTRODUCTION

B. 'WHICH' OBJECT FOR THE TRANSACTION?

1. A top level domain

(a) Private auctions

(b) Sale of a top level domain

(c) Lease of a top level domain

2. A third level domain

3. A second level domain

C. 'WHERE' WILL THE NAME BE USED?

D. 'WHO' WILL HOLD OR USE THE NAME?

1. The case of a transfer

(a) Eligibility

(b) Contact information

(c) Joint registration

2. The case of agreements on use

(a) General principles

(b) Situations of joint use

E. 'WHAT' IS THE NATURE OF THE TRANSACTION?

1. 'Sale' of a domain name

2. License of a domain name

F. CONCLUSION

5. HOW TO MAKE TWO OUT OF ONE: THE INS AND OUTS OF TRADEMARK PORTFOLIO SPLITTING TRANSACTIONS Gregor Bühler and Luca Dal Molin

A. INTRODUCTION
B. PRELIMINARY NOTE ON APPLICABLE LAW 
C. BUILDING BLOCKS OF TRADEMARK PORTFOLIO SPLITTING

1. Overview $\quad 5.09$

2. Free assignability as international standard $\quad 5.10$

3. Partial assignment $\quad 5.12$

$\begin{array}{ll}\text { (a) Overview } & 5.12 \\ \text { (b) Effect of the partial assignment } & 5.14 \\ \text { (c) Limitations } & 5.16\end{array}$

(d) Technicalities under a Swiss law focus $\quad 5.19$

4. Trademark license $\quad 5.23$
(a) Overview $\quad 5.23$
(b) Limitations $\quad 5.26$
(c) Technicalities under Swiss law focus $\quad 5.28$

5. Partial assignment and license grant compared in practice $\quad 5.31$

(a) In general: ownership v. contractual rights 5.31

(b) Affected goods and services $\quad 5.33$

(c) Duration of the post-transactional arrangement $\quad 5.35$

(d) Flexibility of license grants v. restrictions on partial assignments 5.36

(e) License to register new trademarks

D. TRADEMARK PORTFOLIO SPLITTING AGREEMENTS $\quad 5.39$

$\begin{array}{ll}\text { 1. Overview } & 5.39\end{array}$

2. Typical provisions in trademark portfolio splitting agreements $\quad 5.42$

(a) Trademark delimitation and allocation $\quad 5.42$

(b) Implementation of the allocation $\quad 5.46$

(c) Coexistence, non-compete and mutual support 5.51

(d) Scope $\quad 5.52$

(e) Trademark maintenance $\quad 5.53$

(f) Duration and termination $\quad 5.55$

(g) Conflict resolution, governing law, jurisdiction $\quad 5.56$

E. OTHER POSSIBLE OPTIONS AND CONSIDERATIONS

$\begin{array}{ll}\text { 1. Shared ownership } & 5.57\end{array}$

2. Joint ventures $\quad 5.60$

3. Rebranding $\quad 5.61$

F. CONCLUSION

\section{COMPETITION, MARKETS, AND TRADEMARK TRANSACTIONS} Shubha Ghosh
A. INTRODUCTION
B. COMPETITION, INTELLECTUAL PROPERTY, AND TRADEMARKS
6.01
C. CONCEPTS, MODELS, AND TRADEMARK LAW
6.15
D. TRADEMARK TRANSACTIONS: TYING, TRANSFERS IN GROSS AND COVENANTS NOT TO
SUE
6.38
6.71
E. CONCLUSION
6.77

\section{Section C Valuation, Taxation, Security Interests and Bankruptcy}

7. BRAND DIFFERENTIATION AND INDUSTRY SEGMENTATION: DRIVERS FOR TRADEMARK VALUATION IN CORPORATE TRANSACTIONS Roy P. D'Souza

$\begin{array}{ll}\text { A. INTRODUCTION } & 7.01\end{array}$

B. BRAND MANAGEMENT PRINCIPLES $\quad 7.06$

C. COMMON APPROACHES TO VALUE BRANDS $\quad 7.09$

$\begin{array}{ll}\text { 1. Income approach } & 7.10\end{array}$

(a) Relief from royalty $\quad 7.13$

$\begin{array}{ll}\text { (b) Excess earnings } & 7.18\end{array}$

$\begin{array}{ll}\text { 2. Market approach } & 7.20\end{array}$

D. HISTORICAL TRANSACTIONS INVOLVING BRANDS $\quad 7.22$

1. Distressed vs. going concern (brand-only vs. business enterprise with brand) $\quad 7.23$ 
(a) Distressed business enterprise (liquidation/brand only scenario)

(b) Distressed enterprise key transactions $\quad 7.25$

(c) Going concern business enterprise $\quad 7.31$

(d) Going concern business enterprise key transactions $\quad 7.32$

2. Valuation of the brands transacted $\quad 7.37$

(a) Strategic vs. Financial Target $\quad 7.37$

(b) Summary $\quad 7.38$

3. Asset purchase agreements containing trademarks $\quad 7.39$

$\begin{array}{lr}\text { E. PURCHASE PRICE ALLOCATION } & 7.40\end{array}$

$\begin{array}{ll}\text { F. WHY INDUSTRY MATTERS } & 7.41\end{array}$

G. ADDITIONAL BRAND VALUATION METHODS $\quad 7.45$

H. THE WORLD'S MOST VALUABLE BRANDS $\quad 7.46$

$\begin{array}{ll}\text { I. CONCLUSION } & 7.47\end{array}$

8. TRADEMARK TRANSACTIONS AND INTERNATIONAL TAX STRATEGIES Jean-Frédéric Maraia

A. INTRODUCTION

B. OECD - BEPS: GENERAL PRESENTATION $\quad 8.05$

C. TRADEMARK TRANSACTIONS BETWEEN THIRD PARTIES $\quad 8.10$

1. Licensing $\quad 8.12$

(a) Tax treatment of royalties $\quad 8.14$

(b) Impact of double tax treaties in an international context $\quad 8.18$

\begin{tabular}{lr}
2. & Assignment \\
\hline
\end{tabular}

(a) Royalties or capital gains? $\quad 8.27$

(b) Tax treatment of capital gains

(c) Impact of double tax treaties in an international context

3. Tax treatment of expenses $\quad 8.38$

D. TRADEMARK TRANSACTIONS BETWEEN RELATED PARTIES

1. Arm's length principle $\quad 8.43$

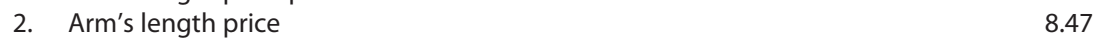

3. Domestic restructuring $\quad 8.54$

$\begin{array}{ll}\text { E. INTERNATIONAL TAX STRATEGIES } & 8.57\end{array}$

1. Residence of companies $\quad 8.59$

2. Ownership $\quad 8.64$

$\begin{array}{ll}\text { 3. Tax status } & 8.69\end{array}$

(a) Auxiliary status (intellectual property companies) $\quad 8.70$

F. CONCLUSION

9. REGISTERING SECURITY INTERESTS OVER TRADEMARKS IN AUSTRALIA: THEORY AND PRACTICE Robert Burrell and Michael Handler
A. INTRODUCTION
B. THE PRE-PPSA POSITION
C. THE PPSA REFORMS
D. TENSIONS BETWEEN THE TRADEMARK AND PPSA SYSTEMS
1. Imperfect information and transition costs
2. Ongoing role of recording claims in the Trade Marks Register
3. Problems caused when title in property passes to the secured party
E. CONCLUSIONS AND OPTIONS FOR REFORM

10. THE INTERSECTION OF TRADEMARKS, LICENSES AND BANKRUPTCY: ENDING UNCERTAINTIES IN THE LAW

\section{Xuan-Thao Nguyen}

A. INTRODUCTION

B. TRADEMARK IN ORDINARY LICENSES 
C. TRADEMARKS IN CORPORATE TRANSACTIONS

10.18

1. Chain v. Tropodyne: sale of assets and trademark use within the acquired division

10.21

2. Seattle Brewing \& Malting Co. v. Commissioner: sale of assets and trademark use restricted to field of use and geographical territory

D. CORPORATE DIVISION SALE OF ASSETS AND TRADEMARK USE IN IN RE EXIDE TECHNOLOGIES

1. In re Exide Technologies

2. Causing uncertainties

10.44

3. Adding uncertainties: In re Interstate Bakeries and In re Lakewood (Sunbeam Prods., Inc. v. Chicago Am. Mfg, LLC)

E. ENDING THE UNCERTAINTIES

1. Looking beyond form, facing the substance

2. Sales, not licenses

10.75

10.79

10.80

(a) Concurrent use doctrine

(b) Co-existence separately

(c) Imperfect coexistence, but do not touch the license

10.91

F. CONCLUSION

10.94

10.95

\section{Section D Dispute Prevention and Settlement Mechanisms}

\section{OUT OF THE SHADOWS: THE UNIQUE WORLD OF TRADEMARK CONSENT AGREEMENTS}

\section{Neil Wilkof}
A. INTRODUCTION
B. THE LEGAL FOUNDATION
1. Assignment
2. License
3. Consent agreement
C. THE VARIOUS CIRCUMSTANCES IN WHICH A CONSENT AGREEMENT MAY ARISE
D. TYPES OF CONSENT AGREEMENT
E. IMPACT ON THE BEHAVIOUR OF THE PARTIES BY VIRTUE OF THE UNDERTAKINGS IN A CONSENT AGREEMENT
F. THE ROLE OF LIKELIHOOD OF CONFUSION
G. PUBLIC AND PRIVATE CONSIDERATIONS
H. CONCLUSION
APPENDIX

11.01

11.02

11.03

11.04

11.06

11.13

11.20

11.25

11.31

11.35

11.42

\section{CHOICE-OF-COURT AND CHOICE-OF-LAW CLAUSES IN INTERNATIONAL TRADEMARK TRANSACTIONS}

\section{Dai Yokomizo}

A. INTRODUCTION

B. CHOICE-OF-COURT CLAUSE

1. Practice

(a) Which country's court is chosen?

(b) Is a choice-of-court clause exclusive or not?

(c) Choice-of-court clause or arbitration clause?

(d) Summary

2. Legal issues

(a) Validity

(b) Limitation

(c) Summary

3. Summary

C. CHOICE-OF-LAW CLAUSE

1. Practice

2. Legal issues

(a) Validity

(b) Scope 
3. Summary 12.41

D. CONCLUSION

13. ALTERNATIVE DISPUTE RESOLUTION MECHANISMS FOR SOLVING TRADEMARK DISPUTES (MEDIATION, UDRP, ARBITRATION) Jacques de Werra
A. INTRODUCTION
B. ADR METHODS FOR SOLVING TRADEMARK DISPUTES
1. Mediation
2. The UDRP
3. UDRP as a model for other ADR systems for trademark-related domain name dis- putes
C. ARBITRATION OF (INTERNATIONAL) TRADEMARK DISPUTES
1. Introduction
2. Conditions and features
(a) Objective arbitrability of intellectual property disputes
(b) Consent of parties to submit to arbitration: the scope of the arbitration clause
13.34
3. Governing law
4. Provisional measures
13.66
D. CONCLUSION

\section{PART II TRADEMARK TRANSACTIONS AT THE REGIONAL AND NATIONAL LEVEL}

Section A Trademark Transactions in Europe

14. TRADEMARK TRANSACTIONS IN EU LAW: REFINING THE APPROACH TO SELECTIVE DISTRIBUTION NETWORKS AND NATIONAL UNFAIR COMPETITION LAW

Martin Senftleben
A. INTRODUCTION
B. OVERVIEW OF HARMONIZED EU RULES
1. Community Trade Mark Regulation
2. Trade Mark Directive
3. Reform plans
C. SELECTIVE DISTRIBUTION NETWORKS
1. The Copad/Dior case
2. Expansion of the concept of product quality
3. Impact on exhaustion of rights
4. Open questions
14.23
5. Rights against the licensee
6. Rights against outside traders
7. A more nuanced approach
14.40
D. ROOM FOR NATIONAL UNFAIR COMPETITION LAW
1. The Martin Y Paz/Depuydt case
2. Mantra of complete harmonization
3. Function theory unsatisfactory
14.52
4. No pre-emption of national doctrines
14.57
E. CONCLUSION

15. UK PERSPECTIVES ON TRADEMARK TRANSACTIONS: A LIBERAL APPROACH Laura Anderson

A. INTRODUCTION 
B. UK LAW AND TRADEMARK TRANSACTIONS

C. ASSIGNMENTS OF UK TRADEMARKS 15.11

1. Assignment of part 15.16

2. Unregistered trademarks $\quad 15.19$

3. Requirements for valid assignment $\quad 15.20$

4. Language 15.21

5. Identification of the intellectual property rights being assigned $\quad 15.22$

$\begin{array}{ll}\text { 6. Consideration } & 15.23\end{array}$

7. Assignment of the right to sue prior infringers $\quad 15.24$

8. Implied covenants as to title $\quad 15.25$

9. Registration 15.30

10. Trusts and equitable assignments of trademarks $\quad 15.32$

11. What is required for an equitable assignment? $\quad 15.35$

$\begin{array}{ll}\text { 12. Confirmatory assignments } & 15.37\end{array}$

D. LICENSES OF UK TRADEMARKS $\quad 15.40$

1. The nature of a trademark license $\quad 15.42$

2. Formalities $\quad 15.44$

3. Key terms $\quad 15.47$

4. Grant and exclusivity $\quad 15.50$

5. Sublicensing 15.52

6. Quality control $\quad 15.54$

7. Liabilities and indemnity 15.62

8. Rights of licensees to bring infringement proceedings $\quad 15.65$

$\begin{array}{ll}\text { 9. Warranties } & 15.71\end{array}$

10. Term and termination $\quad 15.72$

11. Assignment of licenses $\quad 15.77$

12. Contracts Rights of Third Parties Act $\quad 15.81$

13. Registration $\quad 15.83$

14. Licensing of unregistered trademarks $\quad 15.85$

E. SECURITY INTERESTS $\quad 15.86$

F. UK COMPETITION LAW $\quad 15.91$

$\begin{array}{lr}\text { G. CONCLUSIONS } & 15.93\end{array}$

16. TRADEMARK TRANSACTIONS IN GERMANY: A CONTINENTAL EUROPEAN SYSTEM MOVES TOWARDS COMMON UNDERSTANDING WITH THE US Axel Nordemann and Christian Czychowski

A. INTRODUCTION $\quad 16.01$

B. EXISTING LEGAL RULES ON TRADEMARK TRANSACTIONS IN GERMAN LAW 16.02

1. The legal framework - overview $\quad 16.02$

2. Relations between European Union law and German trademark law $\quad 16.11$

3. Sections 27-31 of the MarkenG 16.19

4. The difference between transactions with regard to registered trademarks,
company symbols, and titles of works

C. TRADEMARK TRANSACTIONS IN PRACTICE $\quad 16.33$

$\begin{array}{ll}\text { 1. Purchase agreements } & 16.33\end{array}$

2. License agreements $\quad 16.36$
(a) General
(b) Restrictions imposed by antitrust law
16.36
(c) License agreements and insolvency proceedings
16.40
16.46
(d) Trademark infringements
16.47
(e) Registration of a license
16.49
16.50
16.50
(a) General
16.51
(b) Restrictions imposed by antitrust law
16.53
(c) Applicable law
16.58 
5. Trademarks as securities 16.61

D. CONCLUSION

17. FRENCH PERSPECTIVES ON TRADEMARK TRANSACTIONS: FROM THE CIVIL CODE TO THE BUSINESS LAW?

Nicolas Binctin

A. INTRODUCTION

B. CONTRACTUAL FREEDOM

1. General principles of contract law

(a) Trademark assignment

(b) Trademark licensing

2. Specific dispositions

C. THE TRADEMARK AS AN ELEMENT OF THE FONDS DE COMMERCE

1. Trademark and securities

2. Transfer of trademark

D. TAX CONSIDERATIONS AND TRADEMARK TRANSACTIONS

1. Trademark operations for free

2. The tax qualification of a trademark license as an asset

17.52

3. Tax influence on merger and acquisition qualification

17.54

E. CONCLUSION

\section{Section B Trademark Transactions in North and South America}

18. TRADEMARK TRANSACTIONS IN THE UNITED STATES: TOWARDS A DE FACTO ACCEPTANCE OF TRADING IN GROSS? Irene Calboli
A. INTRODUCTION
B. A BRIEF PRIMER OF TRADEMARK LAW

C. TRADEMARK ASSIGNMENT

1. The current rule on trademark assignment 'with goodwill'

(a) Rationale of the rule

(b) Origin of the rule

2. Judicial developments

(a) Early (conservative) decisions

(b) Shifting towards trademark assignment 'in gross'?

D. TRADEMARK LICENSING

1. The current rule on trademark licensing 'with control'

(a) Rationale of the rule

(b) Origin of the rule

2. Judicial developments

(a) The evolution of the standard

(b) Recent developments

E. STRATEGIC TRADEMARK TRANSACTIONS

1. Trademark assignment and license-back

2. Security interests in trademarks

F. CONCLUSION

19. NEW DRESS CODE FOR BUSINESS TRANSACTIONS IN BRAZIL: ESSENTIALS AND PECULIARITIES OF TRADEMARKS IN THE SPOTLIGHT José Carlos Vaz e Dias
A. INTRODUCTION
B. THE LEGAL NATURE OF TRADEMARKS: OPPORTUNITIES AND LIMITS
C. TRADEMARKS LICENSING
D. TRADEMARK AND FRANCHISING IN BRAZIL
E. TRADEMARK AS COLLATERAL AND SECURITY INTEREST 
G. CONCLUSION $\quad 19.63$

\section{Section C Trademark Transactions in Asia}

20. CHINESE TRADEMARK LAW AND TRADEMARK TRANSACTIONS: A LAW IN TRANSITION IN THE GLOBAL ECONOMY He GUo

$\begin{array}{ll}\text { A. INTRODUCTION } & 20.01\end{array}$

B. EVOLUTION OF THE CHINESE TRADEMARK LAW $\quad 20.03$

$\begin{array}{ll}\text { C. ESTABLISHING TRADEMARK RIGHTS } & 20.12\end{array}$

$\begin{array}{ll}\text { 1. Registered trademarks } & 20.13\end{array}$

(a) Application for trademark registration $\quad 20.13$

(b) Examination of the application for trademark registration $\quad 20.16$

2. Unregistered trademarks $\quad 20.20$

$\begin{array}{ll}\text { D. ASSIGNMENT OF TRADEMARKS } & 20.26\end{array}$

1. Concept and formalities for trademark assignment 20.26

2. Procedures and regulations on trademark assignment $\quad 20.34$

$\begin{array}{ll}\text { E. TRADEMARK LICENSING } & 20.37\end{array}$

1. Type of trademark licenses $\quad 20.40$

2. Obligations of the trademark owners and licensees $\quad 20.42$

(a) Supervision of the quality of the marked goods 20.43

(b) Maintenance of trademark rights $\quad 20.48$

3. Ownership of the goodwill and legal responsibilities after a trademark license
contract is terminated

(a) Ownership of the goodwill 20.50

(b) Legal responsibilities after a trademark license contract is terminated $\quad 20.51$

F. PLEDGE OF TRADEMARKS $\quad 20.53$

1. Definition and legal basis of trademark pledge 20.53

2. Procedural requirements for the pledge of the trademark rights 20.60

3. Effects of the pledge contract of trademark rights 20.65

$\begin{array}{ll}\text { G. CONCLUSION } & 20.67\end{array}$

21. JAPANESE PERSPECTIVES ON TRADEMARK TRANSACTIONS: IS EXPANSIVE TRADEMARK PRACTICE PREVAILING OVER THE CONSERVATIVE STOICISM? Shinto Teramoto

A. INTRODUCTION

B. WHAT IS A 'TRADEMARK'?

1. Scope of 'trademarks' in the context of trademark transactions 21.03

2. 'Trademarks' under the Trademark Act $\quad 21.05$

3. What has changed and what has not in the legal definition of trademarks $\quad 21.07$

4. Laws to be considered when negotiating trademark transactions 21.11

C. LICENSES

1. Definition of 'license' $\quad 21.12$

2. 'Right to use' trademarks provided under the Trademark Act 21.13

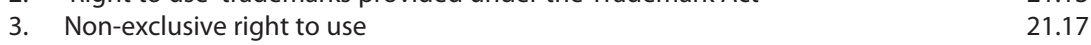

$\begin{array}{ll}\text { 4. Proprietary right to use } & 21.24\end{array}$

5. Licensing agreements for marks not registered under the Trademark Act $\quad 21.29$

6. Governing laws of licensing agreements $\quad 21.38$

\begin{tabular}{ll}
7. & Japanese taxes imposed on royalties \\
\hline
\end{tabular}

8. Termination of licensing agreements $\quad 21.48$

9. Application of the Anti-Monopoly Act $\quad 21.51$

D. TRADEMARK ASSIGNMENTS AND SECURITY INTERESTS $\quad 21.53$

1. General principles $\quad 21.53$

2. Trademarks that simultaneously represent the goodwill of diversified suppliers $\quad 21.56$ 
3. Marks that represent the collective goodwill of multiple suppliers 21.58

4. Non-assignability of regional collective trademark rights 21.61

5. Security interests in trademark rights 21.63

E. CONCLUSION $\quad 21.67$

22. TRADEMARK TRANSACTIONS IN ASEAN: CONVERGENCES AND DIVERGENCES IN EMERGING MARKETS

Susanna H. S. Leong

B. TRADEMARKS AS PROPERTY

22.01

C. ASSIGNMENT OF REGISTERED TRADEMARKS

22.05

1. Assignment of registered trademarks with or without goodwill/business $\quad 22.14$

2. Assignment of an application for registration of a trademark 22.21

3. Formalities: assignments must be in writing $\quad 22.22$

4. Assignment of unregistered trademarks $\quad 22.23$

D. LICENSING OF REGISTERED TRADEMARKS $\quad 22.27$

1. Singapore $\quad 22.30$

2. Vietnam 22.35

3. Thailand 22.38

4. Philippines 22.45

5. Cambodia 22.46

6. Myanmar $\quad 22.47$

7. Brunei 22.48

8. Malaysia 22.50

9. Laos 22.53

10. Indonesia $\quad 22.55$

$\begin{array}{lr}\text { E. REGISTRATION OF TRANSACTIONS } & 22.57\end{array}$

1. Singapore 22.58

2. Vietnam $\quad 22.60$

3. Thailand 22.62

4. Philippines 22.64

5. Cambodia 22.65

$\begin{array}{lr}\text { 6. Myanmar } & 22.67\end{array}$

7. Brunei 22.68

8. Malaysia 22.69

9. Laos 22.72

10. Indonesia 22.73

F. CONCLUSION

23. TRADEMARK TRANSACTIONS IN INDIA: EXPLORING THE GENRE, SCOPE AND CONSEQUENCE Raman Mittal

A. INTRODUCTION

B. LICENSING OF REGISTERED TRADEMARKS UNDER THE TRADE MARKS ACT OF 1999

1. Scope of trademark licensing

2. Term and territorial scope of license

3. Conditions for and extent of use of mark by licensee

4. Procedure for registration, variation, and cancellation of registration

5. Rights and obligations of licensor

(a) Liability for acts of licensee $\quad 23.25$

(b) Right to sue infringers and right to be impleaded 23.26

(c) Right to keep licensing details secret $\quad 23.27$

(d) Obligation to furnish information to the Registrar $\quad 23.28$

6. Rights and obligations of licensee $\quad 23.29$

(a) Use of mark under accompanying legend $\quad 23.30$

(b) Assignment and sublicensing by licensee $\quad 23.31$

(c) Right to initiate infringement proceedings 23.32 
(d) Right to be impleaded

23.35

(e) Right to be notified in case of new license or cancellation

(f) Right over goodwill generated

(g) Proprietorship over the mark

(h) Right to challenge the mark

7. Quality control over the use of the licensed trademark

8. Trafficking under Trade and Merchandise Marks Act of 1958

9. Character merchandising and trademark licensing 23.46

10. Licensing and hybridization of trademarks $\quad 23.48$

C. LICENSING OF UNREGISTERED TRADEMARKS $\quad 23.49$

D. BREACH OF TRADEMARK LICENSE AND CONSEQUENCES

E. ASSIGNMENT OF TRADEMARKS $\quad 23.55$

1. Relation between trademark assignment and assignment of goodwill 23.59

2. Restrictions on assignment $\quad 23.60$

3. Assignment resulting in splitting of trademark on territorial basis 23.62

4. Registration of the assignee of a registered trademark 23.63

5. Assignment of unregistered trademarks $\quad 23.69$

6. Assignment of certification and associated trademarks and discretion of registrar 23.70

F. ROYALTY FOR TRADEMARK TRANSACTIONS AND TREATMENT UNDER TAXATION LAWS

G. CONCLUSION 